\title{
ORNE Learning Model to Improve Problem-Solving Skills of Physics Bachelor Candidates: An Alternative Learning in the Covid-19 Pandemic
}

\author{
Binar Kurnia Prahani 1,a," , Ali Hasbi Ramadani ${ }^{1, b}$, Diah Hari Kusumawati ${ }^{1, c}$, Nadi Suprapto ${ }^{1, d}$, \\ Munasir ${ }^{1, \mathrm{e}}$, Madlazim 1,f, Budi Jatmiko ${ }^{1, \mathrm{~g}}$, Zainul Arifin Imam Supardi ${ }^{1, \mathrm{~h}}$, \\ Husni Mubarok ${ }^{2, \mathrm{i}}$, Nur Shabrina Safitri ${ }^{3, j}$, and Utama Alan Deta ${ }^{1, k}$ \\ ${ }^{1}$ Department of Physics, Faculty of Mathematics and Natural Science, Universitas Negeri Surabaya \\ Jalan Ketintang, Surabaya 60231, Indonesia \\ ${ }^{2}$ Graduate Institute of Digital Learning and Education, National Taiwan University of Science and Technology \\ No.43, Keelung Rd., Sec.4, Da'an Dist., Taipei 10607, Taiwan \\ ${ }^{3}$ College of Education, Central China Normal University \\ Central China Normal University, Luoyu Road, Wuhan, Hubei 430079, PR. China

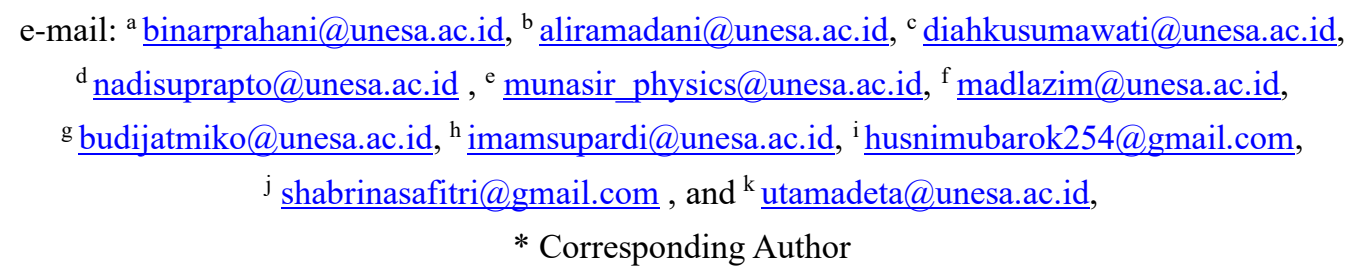

\begin{abstract}
In this industrial revolution 4.0 era, professional science, technology, engineering, and mathematics (STEM) bachelor must have various skills. One of which is problem-solving skills. The development of problem-solving skills (PSS) is very important in higher education. Students must have PSS that must be improved to become excellent graduates, including physics bachelor candidates. Many physics bachelor candidates lack problem-solving skills. This problem is the basis for developing innovative learning models based online that, by design, can improve the problem-solving skills of physics bachelor candidates in the COVID-19 pandemic. This research aims to analyze the effectiveness ORNE learning model in improving the problem-solving skills of physics bachelor candidates as an alternative to online learning in the COVID-19 pandemic. The research design used a true-experiment with a non-equivalent control group design with 58 physics bachelor candidates. Data collected using the problem-solving skills test and then analyzed using the Paired Sample Test, Effect Size, N-gain, and Independent Sample Test. The results showed that the ORNE learning model proved effective in improving physics bachelor candidates' problem-solving skills. This research implies that the ORNE learning model can improve physics bachelor candidates' problem-solving skills as an alternative to online learning in the COVID-19 pandemic.
\end{abstract}

Keywords: COVID-19 Pandemic; Online learning; ORNE learning model; physics bachelor candidates; problem solving skills 
Jurnal Penelitian Fisika dan Aplikasinya (JPFA), 2020; 10(1): 71-80

\title{
Model Pembelajaran ORNE Untuk Meningkatkan Keterampilan Pemecahan Masalah Calon Sarjana Fisika: Sebuah Pembelajaran Alternatif di Pandemi Covid-19
}

\begin{abstract}
Abstrak
Dalam era revolusi industri 4.0 ini, sarjana profesional, sains, teknologi, teknik, dan matematika (STEM) harus memiliki berbagai keterampilan. Salah satunya adalah keterampilan memecahkan masalah. Pengembangan keterampilan pemecahan masalah (PSS) sangat penting dalam pendidikan tinggi. Itu karena mahasiswa harus memiliki PSS yang harus ditingkatkan untuk menjadi lulusan yang unggul, termasuk calon sarjana fisika. Banyak calon sarjana fisika kurang memiliki keterampilan memecahkan masalah. Ini adalah dasar untuk mengembangkan model pembelajaran inovatif berbasis online yang dengan desain dapat meningkatkan keterampilan pemecahan masalah calon sarjana fisika dalam pandemi COVID-19. Fokus dari penelitian ini adalah untuk menganalisis efektivitas model pembelajaran ORNE dalam meningkatkan keterampilan pemecahan masalah calon sarjana fisika sebagai alternatif untuk pembelajaran online dalam pandemi COVID-19. Desain penelitian menggunakan true experiment dengan non-equivalent control group design dengan 58 kandidat sarjana fisika. Data dikumpulkan menggunakan tes keterampilan pemecahan masalah, dan kemudian dianalisis menggunakan Paired Sample Test, Effect Size, N-gain, dan Independent Sample Test. Hasil penelitian menunjukkan bahwa model pembelajaran ORNE terbukti efektif dalam meningkatkan keterampilan pemecahan masalah calon sarjana fisika. Implikasi dari penelitian ini adalah model pembelajaran ORNE dapat meningkatkan keterampilan pemecahan masalah calon sarjana fisika sebagai alternatif untuk pembelajaran online di COVID-19.
\end{abstract}

Kata Kunci: COVID-19 Pandemi; pembelajaran online; model pembelajaran ORNE; calon sarjana fisika; keterampilan pemecahan masalah

PACS: 01.40.-d; 01.40.Fk; 01.40.gb; 01.40.ha

(C) 2020 Jurnal Penelitian Fisika dan Aplikasinya (JPFA) is licensed under CC BY-NC 4.0

Article History: Received: May 25, 2020

Approved with minor revision: June 4, 2020

Accepted: June 25, 2020

Published: June 30, 2020

How to cite: Prahani BK, et al. ORNE Learning Model to Improve Problem-Solving Skills of Physics Bachelor Candidates: An Alternative Learning in the Covid-19 Pandemic. Jurnal Penelitian Fisika dan Aplikasinya (JPFA). 2020; 10(1): 71-80. DOI: https://doi.org/10.26740/jpfa.v10n1.p71-80.

\section{INTRODUCTION}

In this industrial revolution 4.0 era, professional science, technology, engineering, and mathematics (STEM) bachelor must have various skills. One of which is problem-solving skills [1-7]. The development of problem-solving skills (PSS) is very important in higher education. That is because students must have PSS that must be improved to become excellent graduates [5, 8-13], include physics bachelor candidates.

The results of preliminary studies at the State University of Surabaya that there are Binar Kurnia Prahani et al. still many physics bachelor candidates who lack aspects of PSS. That is because there is no PSS learning by design to improve the PSS of physics bachelor candidates. Learning model which can improve PSS of physics bachelor candidates includes: (1) Modeling Instruction (MI) [14-19] and (2) Problem Based Learning (PBL) [20-23].

Therefore, both MI and PBL are often adapted in physics learning to improve the PSS of physics bachelor candidates. The implementation of MI and PBL, however, has some deficiencies. The student model of 
difficulty represents the problem at hand, the difficulty of turning the problem into a model, and students begin to trouble without prior knowledge [5,25]. Meanwhile, research results have shown that applying PBL will be effective in learning when students already have basic concepts $[5,26]$.

Both models have been implemented through face-to-face learning. In fact, now it has switched to online learning. The cause is a COVID-19 pandemic. According to the Task Force for the Acceleration of Handling COVID-19 in Indonesia explained that spread the Corona virus (COVID-19) in Indonesia until Saturday (5/23/2020) at 12.00 WIB, including 21,745 confirmed positive cases, with 5,249 COVID-19 patients (24.1\%) recovering, while 1,351 people received (6.2\%). Meanwhile, worldwide, there are a total of 5,326,230 positive cases of the Corona virus. In the past 24 hours, 949 new positive cases were needed throughout Indonesia. Thus, in the last 3 days, there have been two jumps of more than 900 cases of COVID-19.

Reviewing the development of the COVID-19 pandemic in Indonesia, the chancellor of Surabaya State University issued a policy of (1) lecturers conducting work from home (WFH), (2) face-to-face lectures were canceled as a substitute for online learning, and (3) students continued to learn from home. This is in addition to being positive, but it still creates new problems that not all students and lecturers are ready for online learning. It is necessary to find a solution point to solve the problem so that there is no decline in the quality of physics bachelor candidates.

This is the basis for developing innovative learning models based online that by design can improve PSS of physics bachelor candidates at the State University of Surabaya. The innovative learning model developed is the ORNE learning model that is suitable for increasing the PSS of physics bachelor candidates in the COVID-19 pandemic.

The ORNE learning model is a scientific online learning developed specifically to improve the PSS of physics bachelor candidates who are supported by WhatsApp, PhET, and Youtube applications in every online learning activity. Development of the ORNE learning model is supported by current learning theories (constructivism, observation learning, cognitive processes, discovery learning, multi representation and scaffolding), empirical foundations of current research, and scientific publications of researchers. The focus of this research is to analyze the effectiveness ORNE learning model in improving the PSS of physics bachelor candidates as an alternative to online learning in the COVID-19 pandemic.

\section{METHOD}

Based on the literature study, PSS are the skills of individuals achieving goals and solving problems that are faced systematically [9-13]. Two forms of problem-solving knowledge are expert and novice [10, 27-28]. The indicators of PSS in this research are adapted from Selcuke et al. [29], Siswantoro et al. [5], and Pandiangan et al. [7], those are identification of the problem, planning, implementation, and evaluation.

This research is a kind of Education Design Research (EDR) [30] that uses a true-experimental design with non-equivalent control group design [31]. The selection of sample was based on the Slovin formula, i.e. sample $=\left[\right.$ population $/\left(1+e^{2} \times\right.$ population $\left.)\right]$ with error tolerance e $=5 \%$. A whole sample is 56 physics bachelor candidates who take Fundamental Physics courses at Surabaya State University. The focus of this research is to analyze the ORNE learning model in improving the PSS of physics bachelor 
candidates as an alternative to online learning in the COVID-19 pandemic.

The effectiveness of the ORNE learning model in improving PSS of physics bachelor candidates as alternative online learning in COVID-19 pandemic in terms of 1) There is an increase in PSS of physics bachelor candidates which is statistically significant at $\alpha=5 \%$;2) The minimum of the effect size of ORNE learning model is a moderate effect; 3 ) The minimum of average $\mathrm{N}$-gain PSS of physics bachelor candidates is a moderate category; 4) There is a difference in PSS of physics bachelor candidates between ORNE learning model compared to conventional online learning model which are statistically significant at $\alpha=5 \%$.

The instrument used in collecting data in this study was a Problem Solving Skills Test (valid and reliable was assessed by two experts). Research data in the form of pre-test scores and post-test scores that have been collected after going through a series of prerequisite tests, namely: normality test and homogeneity test are then analyzed using Paired Sample Test, Effect Size, and Independent Sample Test. In addition, the mean level of pre-test and post-test scores is also calculated by using the normalized gain calculation (N-gain) [32].

Table 1. Syntax of ORNE Learning Model

Learning Activities
Phase 1: Orientation (O); Lecturers through the WhatsApp Group
(i.e. WAG) to motivate physics bachelor candidates by presenting
up-to-date phenomena (videos on Youtube) according to the material
to be studied. Physics bachelor candidates are asked to identify
problems in the video. After that, the lecturer presents the objectives
of online learning and reminds the importance of having PSS.

Phase 2: Routine problem solving (R); Lecturers through WAG provide handbooks and worksheets that include Routine Problem Solving. PhET is used as a virtual lab to support completing routine problem-solving tasks. Lecturers act as facilitators, motivators, and educators, and support physics bachelor candidates in completing the Routine Problem-Solving tasks.

Phase 3: Non-routine problem solving $(\mathrm{N})$; Lecturers through WAG provide advanced training in the form of non-routine problem-solving. It contains contextual and update issues (the level of difficulty is above nonroutine problem solving). YouTube application can also be used as an alternative to get information. This phase is expected that physics bachelor candidates have experienced an increase in PSS compared to the previous phase. The lecturer acts as a facilitator, motivator, educator, and student support in completing non-routine problem-solving tasks.

Phase 4: Evaluation (E); Lecturers through WAG involve physics bachelor candidates in evaluating PSS for physics bachelor candidates. The lecturer directs the physics bachelor candidates to condition what needs to be prepared at the next meeting.

\begin{tabular}{ll}
\multicolumn{1}{c}{ Application } & \multicolumn{1}{c}{ Indicators of PSS } \\
\hline WhatsApp, & $\begin{array}{l}\text { Identification of the } \\
\text { Youtube }\end{array}$ \\
\hline
\end{tabular}

$\begin{array}{ll}\text { WhatsApp, } & \text { Identification of the } \\ \text { PhET, Youtube } & \begin{array}{l}\text { problem, planning, } \\ \text { implementation, and } \\ \text { evaluation. }\end{array}\end{array}$

$\begin{array}{ll}\text { WhatsApp \& } & \text { Identification of the } \\ \text { Youtube } & \text { problem, planning, } \\ & \text { implementation, and } \\ & \text { evaluation. }\end{array}$

WhatsApp

Problem Solving

Skills 
The ORNE learning model has four-phase syntax; they are Orientation (O), Routine problem solving (R), Non-routine problem solving $(\mathrm{N})$, and Evaluation $(\mathrm{E})$. Syntax of ORNE learning model in Table 1.

\section{RESULTS AND DISCUSSION}

The results of the normality and homogeneity test of variance showed that the pre-test, post-test, and N-gain scores of PSS were homogeneous and normally distributed for the ORNE learning model and conventional online learning model. Therefore, the impact of the ORNE learning model and conventional online learning model implementation in improving the PSS of physics bachelor candidates by using the Paired Sample Test and effect size. Paired t-test and effect size results are presented in Table 2.

Table 2. The Results of the Paired Sample Test of PSS and Effect Size

\begin{tabular}{ccccccc}
\hline \multirow{2}{*}{ Group } & \multirow{2}{*}{ Sample } & \multicolumn{4}{c}{ Paired Sample Test, $\boldsymbol{\alpha}=\mathbf{5 \%}$} & \multirow{2}{*}{ Effect Size } \\
\cline { 3 - 6 } & & Mean & t & df & p (sig.) & \\
\hline ORNE learning model & 29 & -2.06 & -69.83 & 28 & .000 & .92 \\
(High effect) \\
$\begin{array}{c}\text { Conventional online } \\
\text { learning model }\end{array}$ & 29 & -.18 & -5.53 & 28 & .000 & .31 \\
\end{tabular}

Table 2 shows that the mean scores of PSS for the ORNE learning model and conventional model are -2.06 and - .18 with degrees of freedom (df) are 28, and giving a $t$ value of -69.83 and -5.53 . The result of the Paired Sample Test for each group is significant, because $\mathrm{p}<.05$. Therefore, $\mathrm{t}$ value the negative value, then clearly there is a significant difference at $\alpha=5 \%$ between the pre-test score with the PSS post-test in the ORNE learning model and conventional model. For learning with the ORNE learning model and conventional online learning model, all of them show higher post-test score compared to the pre-test score, or the mean scores of PSS of physics bachelor candidates after each teaching process with the ORNE learning model and conventional online learning model are higher than before.

However, the effect size on the ORNE learning model is higher (high) than the conventional model (low) in increasing the PSS of physics bachelor candidates. Based on the results of the effect size it can be concluded that the ORDE learning model has a major influence on the high PSS of physics bachelor candidates.

Table 3. The PSS Indicators of the ORNE Learning Model and Conventional Model

\begin{tabular}{ccccccccccccc}
\hline \multirow{2}{*}{ Group } & \multicolumn{1}{c}{} & \multicolumn{9}{c}{ Indicators of Problem Solving Skills } & & \\
& & \multicolumn{2}{c}{ IP } & \multicolumn{2}{c}{ P } & & I & E & \multicolumn{2}{c}{ Average } \\
\hline \multirow{3}{*}{ ORNE Learning Model } & $\mathrm{O} 1$ & 1.00 & $\mathrm{~L}$ & $\mathrm{~L}$ & $\mathrm{~L}$ & .45 & $\mathrm{~L}$ & .52 & $\mathrm{~L}$ & .68 & $\mathrm{~L}$ \\
& $\mathrm{O} 2$ & 3.00 & $\mathrm{H}$ & $\mathrm{H}$ & $\mathrm{H}$ & 2.59 & $\mathrm{H}$ & 2.62 & $\mathrm{H}$ & 2.74 & $\mathrm{H}$ \\
& $<\mathrm{g}>$ & 1.00 & $\mathrm{H}$ & $\mathrm{H}$ & $\mathrm{H}$ & .84 & $\mathrm{H}$ & .85 & $\mathrm{H}$ & .90 & $\mathrm{H}$ \\
\hline \multirow{2}{*}{ Conventional Online } & $\mathrm{O} 1$ & 1.00 & $\mathrm{~L}$ & .76 & $\mathrm{~L}$ & .48 & $\mathrm{~L}$ & .59 & $\mathrm{~L}$ & .71 & $\mathrm{~L}$ \\
Learning Model & $\mathrm{O} 2$ & 1.59 & $\mathrm{M}$ & .86 & $\mathrm{~L}$ & .52 & $\mathrm{~L}$ & .62 & $\mathrm{~L}$ & .90 & $\mathrm{~L}$ \\
& $<\mathrm{g}>$ & .29 & $\mathrm{~L}$ & .05 & $\mathrm{~L}$ & .01 & $\mathrm{~L}$ & .01 & $\mathrm{~L}$ & .09 & $\mathrm{~L}$ \\
\hline
\end{tabular}

Note = O1 (Pre-test); O2 (Post-test); <g> (N-gain); L (Low); M (Moderate); H (High); IP (Identification of the Problem); P (Planning); I (Implementation); E (Evaluation) 
Table 3 explains that before learning the results of all PSS indicators (ORNE learning models and conventional online learning model) were in the low category. Positive results can be seen after the implementation of the ORNE learning model that all indicators of PSS of physics bachelor candidates are in the high category. However, negative results are obtained in conventional online learning model where only 1 indicator PSS (i.e. identification of the problem) has a moderate category, the other is only a low category.

Another positive finding from this research is that the N-gain of all PSS of physics bachelor candidates after using the ORNE learning model is the high category.
However, the conventional model implementation results found that the $\mathrm{N}$-gain of all indicators of the PSS of physics bachelor candidates is low category. To analyze the ORNE learning model or the conventional online learning model is more effective in increasing PSS from physics bachelor candidates, using the Independent Sample Test on the average N-gain PSS of physics bachelor candidates. Independent Sample Test for the average $\mathrm{N}$-gain was performed on the ORNE learning model and conventional online learning model. The results of the Independent Sample Test on the average $\mathrm{N}$-gain for the ORNE learning model and the conventional online learning model are presented in Table 4.

Table 4. Independent Sample Test Results on the Average N-gain for the ORNE Learning Model and

Conventional Online Learning Model

\begin{tabular}{|c|c|c|c|c|c|c|}
\hline \multirow[b]{2}{*}{ Group } & \multirow[b]{2}{*}{ Sample } & \multicolumn{5}{|c|}{ Independent Sample Test } \\
\hline & & Mean Difference & $\begin{array}{l}\text { Std. error } \\
\text { mean }\end{array}$ & $\mathbf{t}$ & df & $\mathbf{p}$ \\
\hline $\begin{array}{l}\text { ORNE learning model \& conventional } \\
\text { online learning model }\end{array}$ & 58 & .81 & .02 & 46.31 & 56 & .000 \\
\hline
\end{tabular}

Table 4 explains the difference in the average $\mathrm{N}$-gain PSS for ORNE learning models and conventional online learning model is .81. It was proven that the score was significant, because $\mathrm{p}<.05$. These results prove that there are significant differences in the average PSS N-gain score in the ORNE learning model and the conventional online learning model, for each at $\alpha=5 \%$. The results of the above analysis show that the average $\mathrm{N}$-gain of PSS of physics bachelor candidates was higher after online learning with the ORNE learning model and conventional online learning model. While teaching with the ORNE learning model gave higher average $\mathrm{N}$-gain when compared to the conventional model. The key to the ORNE learning model is to improve the PSS of physics bachelor candidates placed in phase 2 (routine problem solving) and phase 3 (non-routine problem solving). The transfer activity of problem-solving skills is based on a positive transfer theory [33]. In addition, learning based on constructivist theory can improve student knowledge [24,33-35]. Reinforced research results about students will support the concepts they have by transferring to new topics, thereby increasing information that can be more numerous [36-37].

Novelty of ORNE learning model by lecturers and physics bachelor candidates:

1. It assisted by Youtube application; lecturers and physics bachelor candidates can find out information about the latest up to date information in the world (i.e. routine or non-routine problem solving).

2. It assisted by WhatsApp application; physics bachelor candidates can easily communicate with lecturers and other 
students. Why use WhatsApp? This application is the most commonly used physics bachelor candidates. In addition, WhatsApp does not require large internet quotas (this is an economical aspect faced by low-budget students like in Indonesia).

3. It assisted by PhET (link); physics bachelor candidates can carry out routine problem-solving activities by using PhET as a substitute for real experiments in the laboratory. $\mathrm{PhET}$ provides free access that is very compatible with the culture and financial of physics bachelor candidates like in Indonesia.

4. The integration of WhatsApp, PhET, and Youtube applications in the implementation of the ORNE learning model makes it easy for lecturers to improve the PSS of physics bachelor candidates in Indonesia.

The effectiveness of ORNE learning model is supported by the results of research [5-7, 36-42] that the products (models, methods, strategies, materials) which meet the validity, practicality, and effectiveness will improve and achieve the learning objectives. Therefore, the ORNE learning model proved effective in improving the problem-solving skills of physics bachelor candidates as an alternative to online learning in the COVID-19 pandemic.

\section{CONCLUSION}

The ORNE learning model is a scientific online learning developed specifically to improve the PSS of physics bachelor candidates supported by WhatsApp, $\mathrm{PhET}$, and Youtube applications. The key to the ORNE learning model is to improve the PSS of physics bachelor candidates placed in phase 2 (routine problem solving) and phase 3 (non-routine problem solving). The results showed that the ORNE learning model proved effective in improving the problem-solving skills of physics bachelor candidates. The implication of this research is the ORNE learning model can improve problem-solving skills of physics bachelor candidates as an alternative to online learning in the COVID-19 pandemic. Further research can be done to compare the effectiveness of ORNE learning models with MI and PBL in online learning.

\section{REFERENCES}

[1] Stohlmann M, Moore T, and Roehrig G. Considerations for Teaching Integrated STEM Education. Journal of Pre-College Engineering Education Research. 2012; 2(1): 28-34. DOI:

https://doi.org/10.5703/1288284314653.

[2] Sassler S, Michelmore K, and Smith K. A tale of two majors: Explaining the Gender Gap in STEM Employment Among Computer Science and Engineering Degree holders. Social Science. 2017; 6(3): 69. DOI: https://doi.org/10.3390/socsci6030069.

[3] Schuster D. In Pursuit of Sustainable STEM Certification Programs. Journal of College Science Teaching. 2013; 42(4): 38-45. Available from:

https://www.jstor.org/stable/43631919.

[4] Griffin P and Care E. Assessment and Teaching of 21st Century Skills: Methods and Approach. New York: Springer; 2015.

[5] Siswanto J, Susantini E, and Jatmiko B. Practicality and Effectiveness of the IBMR Teaching Model to Improve Physics Problem Solving Skills. Journal of Baltic Science Education. 2018; 17(3): 381-394. Available from:

http://oaji.net/articles/2017/987-1529508735 .pdf.

[6] Jatmiko B, Widodo W, Martini, Budiyanto $\mathrm{M}$, Wicaksono I, and Pandiangan $\mathrm{P}$. Effectiveness of the INQF-based on Learning on a General Physics for Improving Student's Learning Outcomes. Journal of Baltic Science Education. 2016; 
Jurnal Penelitian Fisika dan Aplikasinya (JPFA), 2020; 10(1): 71-80

15(4): 441-451. Available from: http://journals.indexcopernicus.com/abstract. php?icid $=1217757$.

[7] Pandiangan P, Sanjaya IGM, and Jatmiko B. The Validity and Effectiveness of Physics Independent Learning Model to Improve Physics Problem Solving and Self-Directed Learning Skills of Students in Open and Distance Education Systems. Journal of Baltic Science Education. 2017; 16(5): 651-665. Available from:

http://oaji.net/articles/2017/987-1509213674 .pdf.

[8] Phumeechanya $\mathrm{N}$ and Wannapiroon $\mathrm{P}$. Design of Problem-based with Scaffolding Learning Activities in Ubiquitous Learning Environment to Develop Problem-solving Skills. Procedia-Social and Behavioral Sciences. 2014; 116: 4803-4808. DOI: https://doi.org/10.1016/j.sbspro.2014.01.102 8.

[9] Docktor LJ, Strand EN, Mestre PJ, and Ross HB. Conceptual Problem Solving in High School Physics. Physical Review Physics Education Research. 2015; 11: 020106. DOI: https://doi.org/10.1103/PhysRevSTPER.11.0 20106.

[10] Fakcharoenphol W, Morphew JW, and Mestre JP. Judgments of Physics Problem Difficulty among Experts and Novices. Physical Review Physics Education Research. 2015; 11: 020128. DOI: https://doi.org/10.1103/PhysRevSTPER.11.0 20128.

[11] Teodorescu RE, Bennhold C, Feldman G, and Medsker L. Curricular Reforms that Improve Students' Attitudes and Problem-solving Performance. European Journal of Physics Education. 2014; 5(1), 15-44. Available from:

http://www.eu-journal.org/index.php/EJPE/a rticle/view/60.

[12] Ibrahim B and Robelo S. Role of Mental Representations in Problem Solving Students' Approaches to Nondirected Tasks.
Physical Review Physics Education Research. 2013; 9: 020106. DOI: https://doi.org/10.1103/PhysRevSTPER.9.02 $\underline{0106}$.

[13] Walsh LN, Howard GR, and Bowe B. Phenomenographic Study of Students' Problem Solving Approaches in Physics. Physical Review Physics Education Research. 2007; 3: 020108. DOI: https://doi.org/10.1103/PhysRevSTPER.3.02 $\underline{0108}$.

[14] Hestenes D. Toward a Modeling Theory of Physics Instruction. American Journal of Physics. 1987; 55(5), 440-454. DOI: https://doi.org/10.1119/1.15129.

[15] Wells M, Hestenes D, and Swackhamer G. A Modeling Method for High School Physics Instruction. American Journal of Physics. 1995; 63(7), 606-619. DOI: https://doi.org/10.1119/1.17849.

[16] Halloun IA. Mediated Modeling in Science Education. Science \& Education. 2007; 16, 653-697. DOI: https://doi.org/10.1007/s11191-006-9004-3.

[17] Malone KL. The Convergence of Knowledge Organization, Problem-solving Behavior, and Metacognition Research with the Modeling Method of Physics Instruction-part II. Journal of Physics Teacher Education Online, 2007; 4(2), 3-15. Available from: http://www2.phy.ilstu.edu/ cjwennin/jpteo/i ssues/jpteo4(2)win07.pdf\#page $=3$.

[18] Jackson J, Dukerich L, and Hestenes D. Modeling instruction: An Effective Model for Science Education. Science Educator, 2008; 17(1), 10-17. Available from: https://files.eric.ed.gov/fulltext/EJ851867.pd f.

[19] Wright TL. The Effects of Modeling Instruction on High School Physics Academic Achievement. Tennessee: ETD Collection for Tennessee State University; 2012. 
Jurnal Penelitian Fisika dan Aplikasinya (JPFA), 2020; 10(1): 71-80

[20] Skinner VJ, Braunack-Mayer A, and Winning TA. The Purpose and Value for Students of PBL Groups for Learning. Interdisciplinary Journal of Problem Based Learning. 2015; 9(1): 19-32. DOI: https://doi.org/10.7771/1541-5015.1499.

[21] Ageorges P, Bacila A, Poutot G, and Blandin B. Some Lessons From a 3-year Experiment of Problem Based Learning in Physics in a French School of Engineering. American Educational Research Journal. 2014; 2(8): 564-567. DOI:

https://doi.org/10.12691/education-2-8-1.

[22] Temel S. The Effect of Problem-based Learning on Pre-service Teacher's Critical Thinking Dispositions and Perceptions of Problem Solving Ability. South African Journal of Education. 2014; 34(1): 769. DOI:

https://doi.org/10.15700/201412120936.

[23] Klegeris A, Bahniwal M, and Hurren $H$. Improvement in Generic Problem-solving Abilities of Student by Use of Tutor-less Problem-based Learning in a Large Classroom Setting. CBE--Life Sciences Education. 2013; 12(1): 73-79. DOI: https://dx.doi.org/10.1187\%2Fcbe.12-06-00 $\underline{81}$.

[24] Arends RI. Learning to Teach. New York: Mc. Graw-Hill Companies; 2012.

[25] Brewe E. Modeling Theory Applied: Modeling Instruction in Introductory Physics. American Journal of Physics. 2008; 76(12): 1155-1160. DOI: https://doi.org/10.1119/1.2983148.

[26] Sockalingam N and Schmidt HG. Characteristics of Problems for Problem Based Learning: The Students Perspective. Interdisciplinary Journal of Problem Based Learning. 2011; 5(1): 6-33. DOI: https://doi.org/10.7771/1541-5015.1135.

[27] Teodorescu ER, Bennhold C, Feldman G, and Medsker L. New Approach to Analyzing Physics Problems: A Taxonomy of Introductory Physics Problems. Physical
Review Physics Education Research. 2014; 9 : 010103. DOI:

https://doi.org/10.1103/PhysRevSTPER.9.01 $\underline{0103}$.

[28] Docktor JL, Mestre JP, and Ross BH. Impact of a Short Intervention on Novices' Categorization Criteria. Physical Review Physics Education Research. 2012; 8: 020102. DOI: http://dx.doi.org/10.1103/PhysRevSTPER.8. $\underline{020102 .}$.

[29] Selcuke GS, Caliskan S, Erol M. The Effects of Problem Solving Instruction on Physics Achievement, Problem Solving Performance and Strategy Use. Latin-American Journal of Physics Education. 2008; 2(3): 151-166. Available from:

http://www.lajpe.org/sep08/01_Gamze_Sezg in.pdf.

[30] Nieveen, N., McKenney, S. and van. Akker. Educational Design Research. New York: Routledge; 2007.

[31] Fraenkel J, Wallen N, Hyun H. How to Design and Evaluate Research in Education. New York: McGraw-Hill; 2012.

[32] Hake RR. Interactive-engagement versus Traditional Methods: Six-thousand-student Survey of Mechanics Test Data for Introductory Physics Courses. American Journal of Physics. 1998; 66(1): 64-74. DOI: http://dx.doi.org/10.1119/1.18809.

[33] Moreno R. Educational Psychology. New Mexico: John Wiley \& Sons, Inc; 2010.

[34] Slavin ER. Educational Psychology: Theory and Practice. Boston: Pearson; 2011.

[35] Solso RL, MacLin OH, MacLin MK. Cognitive Psychology. Boston: Pearson Education; 2008.

[36] Hariadi B, Sunarto MJD, Sudarmaningtyas P, Jatmiko B. Hybrid Learning by Using Brilian Applications as One of the Learning Alternatives to Improve Learning Outcomes in College. International Journal of Emerging Technology Learning. 2019; 
Jurnal Penelitian Fisika dan Aplikasinya (JPFA), 2020; 10(1): 71-80

14(10), 34-45. DOI:

https://doi.org/10.3991/ijet.v14i10.10150.

[37] Celik P, Onder F, Silay I. The Effects of Problem-based Learning on the Students' Success in Physics Course. Procedia-Social and Behavioral Sciences. 2011; 28: 656-600. DOI:

https://doi.org/10.1016/j.sbspro.2011.11.124

[38] Habibbulloh M, Jatmiko B, Wahono W. The Development of Learning Media in Guided Discovery Learning Model Based on Virtual Lab to Reduce Student's Misconception in Vocational High School on Photoelectric Effect Topic. Jurnal Penelitian Fisika dan Aplikasinya (JPFA. 2017; 7(1): 27-43. DOI: http://dx.doi.org/10.26740/jpfa.v7n1.p27-43.

[39] Wicaksono I, Wasis, Madlazim. The Effectiveness of Virtual Science Teaching Model (VS-TM) to Improve Student's Scientific Creativity and Concept Mastery on Senior High School Physics Subject. Journal of Baltic Science Education. 2017; 16(4): 549-561. Available from: http://oaji.net/articles/2017/987-1503905158 .pdf.
[40] Astutik S. Pengembangan Model Collaborative Creativity untuk Meningkatkan Kreativitas Ilmiah dan Afektif Collaborative siswa SMP. Surabaya: Pascasarjana Unesa; 2017.

[41] Astutik S, Nur M, and Susantini E. Validity of Collaborative Creativity (CC) Models. Proceedings of The 3 International Conferences on Research, Implementation and Education of Mathematics and Science, Yogyakarta: UNY. 2016; 73-78.

[42] Plomp T. Preparing Education for the Information Society: The Need for New Knowledge and Skills. International Journal of Social Media and Interactive Learning Environments. 2013; 1(1): 3-18. DOI:

https://doi.org/10.1504/IJSMILE.2013.051 651. 